\title{
Absence of countergradient and cogradient variation in an oceanic silverside, the California grunion Leuresthes tenuis
}

\author{
Elizabeth E. Brown*, Hannes Baumann, David O. Conover \\ School of Marine and Atmospheric Sciences, Stony Brook University, Stony Brook, New York 11794-5000, USA
}

\begin{abstract}
Spatial adaptations that maximize a species' fitness in its local environment, particularly in the form of countergradient variation (CnGV = genotypic influences counteract environmental effects on trait variation) and cogradient variation (CoGV = genotypic influences accentuate environmental plasticity), have been documented in many estuarine and anadromous fishes. However, their prevalence in more oceanic fishes, where extensive gene flow and reduced environmental selection may preclude local adaptation, remains unclear. If oceanic species lack genetic structure, they may be limited in their ability to adapt to global climate change. We examined the potential for adaptation in oceanic fishes by testing whether an oceanic silverside, the California grunion Leuresthes tenuis, displays CnGV in growth capacity and CoGV in vertebral number across a latitudinal gradient as found in estuarine silversides. Common garden experiments revealed that reaction norms for growth in response to temperature differed little among 3 $L$. tenuis populations from different latitudes. Growth rates of wild adult $L$. tenuis measured from scale analysis suggested that growth may be slightly faster at more southern latitudes, likely due to environmental variation. Mean vertebral number in wild $L$. tenuis, determined from radiographs, were nearly identical for all populations. Overall, our results did not provide evidence for spatial adaptations in these traits of $L$. tenuis, in contrast to the strong patterns of latitudinal trait adaptation in other, more estuarine silversides. This study provides support for the finding that higher gene flow levels and weaker environmental selection pressures of oceanic species limit local adaptation.
\end{abstract}

KEY WORDS: Latitudinal gradient · Gene flow · Adaptation · Growth capacity · Vertebral number · Climate change $\cdot$ Environmental selection Resale or republication not permitted without written consent of the publisher

\section{INTRODUCTION}

Species distributed across broad environmental gradients, such as those that occur along latitudes or altitudes, often exhibit phenotypic variation in physiological and morphological traits. This variation is likely due to a combination of environmental influences on phenotypic expression (i.e. phenotypic plasticity) and adaptive genetic variations that maximize a species' fitness in its local environment (Conover et al. 2009). Examination of the co-variation between genetic and environmental influences within species may reveal spatial patterns of adapta- tion to natural environmental variation. Additionally, this knowledge may provide clues to potential evolutionary responses to temporal environmental change (Deutsch et al. 2008, Baumann \& Conover 2011), which is becoming increasingly important to understand as global climate change may alter species distributions and life histories.

Spatial adaptations have been found in a number of marine species, particularly in coastal fishes (reviewed by Conover et al. 2009). However, the majority of these cases are estuarine or anadromous fishes, while fewer examples involve more oceanic fishes (Conover et al. 2009). Therefore it remains 
unclear whether local adaptations are common in oceanic fishes as well. For estuarine fishes, mixing among populations is likely to be partially restricted, hence enabling local adaptation (Conover et al. 2006), while broad-scale dispersal and high levels of mixing may limit the extent to which local adaptations can evolve in oceanic species (Felsenstein 1976, Slatkin 1987). However, strong selection pressures may, in some cases, override high gene flow, thereby allowing adaptations to exist (Schneider et al. 1999, Saint-Laurent et al. 2003). Additionally, the more homogenous environments of oceanic fishes compared to estuarine fishes may result in weaker environmental selection pressures, also making spatial adaptations less likely. If oceanic species tend to lack genetic structure, they may be limited in their ability to respond to climate change, since populations may not be able to respond differently across their range (Garcia-Ramos \& Kirkpatrick 1997, Lenormand 2002).

In estuarine and anadromous fishes, as well as many other species, 2 commonly documented types of spatial adaptation patterns are countergradient (CnGV) and cogradient variation (CoGV) (reviewed by Conover et al. 2009). CnGV occurs when individuals with different genotypes are distributed across the environment such that genetic influences on trait variation oppose environmental influences, thereby resulting in diminished phenotypic expression across the environmental gradient (Levins 1968). In contrast, CoGV occurs when individuals with different genotypes are distributed across an environmental gradient such that genetic and environmental influences are reinforcing and thus increasing overall phenotypic variation (Levins 1969, Conover \& Schultz 1995). CnGV is often observed for physiological traits, while CoGV is more common for morphological traits (Conover et al. 2009).

For instance, estuarine silverside fishes (Atherinopsidae) along the Atlantic (Menidia menidia and $M$. peninsulae) and Pacific (Atherinops affinis) coasts of North America display CnGV in growth capacity, whereby northern populations show higher genetic growth capacities (= temperature-specific growth rate at unlimited food) compared to more southern populations. This enables them to compensate for reduced growing seasons and colder average temperatures that occur at high versus low latitudes (Conover \& Present 1990, Yamahira \& Conover 2002, Baumann \& Conover 2011). In addition, vertebral number increases with latitude in Atlantic and Pacific silversides (Jordan's Rule; Jordan 1891), due to reinforcing environmental and genetic influences, representing a CoGV pattern (Billerbeck et al. 1997,
Yamahira et al. 2006, Baumann et al. 2012). Higher vertebral numbers at northern latitudes may be adaptive for enhanced swimming abilities in colder, more viscous waters (Swain 1992a).

Although fewer, some cases of $\mathrm{CnGV}$ and $\mathrm{CoGV}$ have also been documented for oceanic species (reviewed by Conover et al. 2009). For example, Atlantic cod Gadus morhua, displays CnGV in growth patterns similar to those of estuarine silverside fishes (Salvanes et al. 2004). Two flatfish species, turbot and halibut, have also been shown to exhibit CnGV in growth (Imsland et al. 2000, Jonassen et al. 2000), and a reef fish, the neon damselfish, was found to show CnGV in egg size and number (Kokita 2003), although in these species mixing may be more limited compared to other oceanic fishes (Fairbairn 1981, Grant et al. 1984, Diakov 1998, Foss et al. 1998, Shulman 1998).

To better understand the effects of oceanic versus estuarine life history on the occurrence of local adaptation, we studied spatial patterns of genetic variation in growth capacity and vertebral number in an oceanic member of the silverside family, the California grunion Leuresthes tenuis. L. tenuis has a similar life history to other silversides, but adults spend their life in the coastal ocean and spawn on oceanfront beaches, instead of the intertidal zone of semi-enclosed bays and estuaries (Walker 1952, Eschmeyer et al. 1983). Population studies of $L$. tenuis suggest that the species exhibits panmixia, with high mixing and little divergence among populations (Gaida et al. 2003, Johnson et al. 2009). Absence of local adaptation in growth and vertebral number of $L$. tenuis would suggest that oceanic species are less likely to show local adaptations than estuarine fishes. Conversely, if local adaptation patterns can be detected in L. tenuis, it would confirm the ubiquity and importance of adaptive trait variation even in species considered to have high population mixing.

To measure plastic and genetic trait variation in Leuresthes tenuis, we used common garden experiments, raising offspring from populations sampled at multiple latitudes under the same environmental conditions. Such experiments reveal the genetic component of differences in trait reaction norms among populations. Population trait reaction norms that are parallel but differ in elevation in rank order with their location across a natural gradient indicate a CnGV or CoGV pattern (Conover et al. 2009). Additionally, we measured phenotypic variation in vertebral number and growth in wild $L$. tenuis populations. 


\section{MATERIALS AND METHODS}

\section{Study species}

Leuresthes tenuis (Atherinopsidae) is commonly found along the North American Pacific coast from Punta Abreojos, Mexico $\left(26.7^{\circ} \mathrm{N}\right)$ to Point Conception, California, USA $\left(34.5^{\circ} \mathrm{N}\right)$ (Eschmeyer et al. 1983), with a small population occasionally found in Monterey, California (36.6 ${ }^{\circ} \mathrm{N}_{i}$ Phillips 1943, Bernardi et al. 2003, Roberts et al. 2007). The fish reach a maximum age of 3 to $4 \mathrm{yr}$ and spawn by the end of their first year (Clark 1925). L. tenuis is a gonochoristic, multiple batch spawner that breeds from late February/early March to August/early September on sandy open-ocean beaches (Walker 1952). Spawning is tidally controlled, taking place on the 3 to 4 nights surrounding the new and full moon following the high tide (Walker 1949, 1952). The eggs remain buried in the sand for $\sim 2$ wk until they are washed out to sea by the next spring tide (Walker 1952, Moffatt \& Thomson 1978). Hatching is quickly triggered by the agitation action of waves (Griem \& Martin 2000). Individuals of $L$. tenuis are thought to remain in near-shore oceanic waters for the majority of their life (Eschmeyer et al. 1983), but little is known about habitat utilization outside the spawning season.

\section{Leuresthes tenuis specimen collection and laboratory rearing}

During the first year (2009), fertilized Leuresthes tenuis eggs and mature adults were collected from 3 locations along the North American Pacific coast, spanning the primary spawning range of the grunion: Ensenada, Mexico $\left(\mathrm{P} 1 ; 32^{\circ} \mathrm{N}\right)$, Malibu, California $\left(\mathrm{P} 2 ; 34^{\circ} \mathrm{N}\right)$, and Monterey, California (P3; $37^{\circ} \mathrm{N}$, Table 1). During the second year (2010) collec-

Table 1. Leuresthes tenuis. Sampling sites, site identification, and dates

\begin{tabular}{|c|c|c|c|}
\hline Sampling site & Location & Site ID & Sampling dates \\
\hline $\begin{array}{l}\text { Ensenada, } \\
\text { Mexico }\end{array}$ & $\begin{array}{l}31.9^{\circ} \mathrm{N} \\
116.6^{\circ} \mathrm{W}\end{array}$ & P1 & $\begin{array}{c}\text { 25-26 Apr 2009, } \\
30 \text { Apr-1 May 2010 }\end{array}$ \\
\hline $\begin{array}{l}\text { Malibu, } \\
\text { CA, USA }\end{array}$ & $\begin{array}{l}34.0^{\circ} \mathrm{N} \\
118.8^{\circ} \mathrm{W}\end{array}$ & P2 & $\begin{array}{c}11 \text { May 2009, } \\
\text { 29-30 May (eggs) } \\
\text { 29 Jun (adults) 2010 }\end{array}$ \\
\hline $\begin{array}{l}\text { Monterey, } \\
\text { CA, USA }\end{array}$ & $\begin{array}{l}36.6^{\circ} \mathrm{N} \\
121.9^{\circ} \mathrm{W}\end{array}$ & P3 & 7 June 2009 \\
\hline
\end{tabular}

tions were made only at sites P1 and P2 due to a lack of spawning fish at site P3. Mature L. tenuis were collected by hand during their beach spawning runs and immediately strip-spawned on the beach. Twelve to 20 females and more than 20 males were used for strip-spawning, except for the northernmost population where a smaller spawning run dictated smaller sample sizes ( 5 females and 8 males). Eggs and milt were mixed in plastic containers to ensure genetic diversity. Eggs were wrapped in damp paper towels, stored in 21 water coolers, and transported to our laboratory facility (Flax Pond, Stony Brook University, Long Island, New York, USA) within 36 to $60 \mathrm{~h}$ post fertilization. Upon arrival, eggs were placed in aerated $20 \mathrm{l}$ containers in a large temperaturecontrolled bath $(700 \mathrm{l})$ pre-set to $21^{\circ} \mathrm{C}$. Each $20 \mathrm{l}$ container had 3 holes (5 $\mathrm{cm}$ diameter) covered with $400 \mu \mathrm{m}$ mesh to ensure water exchange within the bath. The photoperiod was $15 \mathrm{~L}: 9 \mathrm{D}$ and the salinity was $30 \pm 2$ psu. $L$. tenuis larvae hatched 8 to $10 \mathrm{~d}$ after fertilization and were immediately fed rotifers Brachionus plicatilis (Atlantis Marine World) and newly hatched brine shrimp Artemia salina nauplii (San Francisco strain, Brine Shrimp Direct).

Growth trials started $\sim 1$ wk after hatching when larvae had reached a total length (TL, mean $\pm \mathrm{SD}$ ) of $7.8 \pm 1.3 \mathrm{~mm}$. The first experiment (Expt 1), conducted in 2009, was carried out at 21 and $25^{\circ} \mathrm{C}$, while an attempted third treatment at $15^{\circ} \mathrm{C}$ resulted in very low survival $(<10 \%)$. For the second experiment (Expt 2), in 2010, temperature treatments were 17,21 , and $25^{\circ} \mathrm{C}$. For each population, 40 larvae were randomly placed into each of 3 replicate containers (20 l) per temperature treatment. In addition, a random sample of 15 to 20 larvae was sacrificed for initial TL measurements (nearest $0.1 \mathrm{~mm}$ using calibrated digital photos and the software ImagePro in 2009 or Image $\mathrm{J}$ in 2010) and pooled wet weight (WW; nearest $0.1 \mathrm{mg}$, Mettler AE163, 2010 only). Fish were provided with daily excess rations of newly hatched brine shrimp nauplii. During the first $3 \mathrm{~d}$ of the experiment, dead larvae were replaced to compensate for mortality due to handling. Halfway through Expt 1 (20-22 mm, 21-42 d), a sub-sample of 8 to 15 fish from each container was sacrificed for TL (0.1 mm, using calipers) and WW measurements. Halfway through Expt 2, a live well was used to quickly measure TL $(1 \mathrm{~mm})$ on live fish. Growth trials were ended when fish reached a TL of $38.2 \pm$ $3.0 \mathrm{~mm}$ (mean $\pm \mathrm{SD} ; 49-94 \mathrm{~d}$ ), at which point all remaining fish were sacrificed to obtain final TL and WW measurements. Growth capacity in length (or weight) was calculated for each replicate by divid- 
ing the difference in mean TL (or ln WW) by the experimental duration for each period (i.e. initial to final, initial to mid, and mid to final). Total percent mortality per replicate averaged $30 \%$ in 2009 and $23 \%$ in 2010.

There were some exceptions to the above protocol during Expt 1. In 2009, the number of surviving larvae allowed for only 2 replicates per temperature for $\mathrm{P} 3$, and replicates for $\mathrm{P} 1$ at $25^{\circ} \mathrm{C}$ contained 33, 33, and 37 fish, respectively.

\section{Age and growth analysis in wild fish}

Scales were removed from a subset of mature wild Leuresthes tenuis (35 to 60 fish population ${ }^{-1} \mathrm{yr}^{-1}$ ) from P1 and P2 in 2009 and 2010 for age and growth analysis. About 15 to 20 scales fish ${ }^{-1}$ were taken from just below the silver lateral band between the origin of the first dorsal fin and the posterior margin of the second dorsal fin (consistent with Clark 1925) and pressed (Carver Scale Press) onto slides. Annuli were indentified and counted by looking for ridges running obliquely to the preceding ridges and a narrow zone of broken ridges in the anterior region that occurs just before the annulus (Clark 1925). Since $L$. tenuis lay down a breeding annulus during late July or August, rather than the typical winter annulus (Clark 1925), a fish captured in early summer with 0 annuli is actually an age 1 fish, a fish with 1 annulus is age 2, and so on. Scale measurements were made from the core to the center anterior tip and from the core to the first annulus (when present) on the 3 clearest scales for each fish. A scale-length:fishlength relationship was constructed for each population, and lengths at age 1 were back-calculated using the Fraser-Lee formula:

$$
L_{1}=C+\left(L_{\mathrm{C}}-C\right) \times\left(S_{1} / S_{\mathrm{C}}\right)
$$

where $L_{1}=$ back-calculated length at age $1, c=$ intercept of the scale to fish length regression, $L_{\mathrm{C}}=$ length of fish at capture, $S_{1}=$ mean length to the first annulus, and $S_{\mathrm{c}}=$ mean scale length at capture. Average growth during Year $1\left(\mathrm{~mm} \mathrm{~d}^{-1}\right)$ was then calculated by dividing the back-calculated length at age by $365 \mathrm{~d}$.

\section{Vertebral number analysis}

Radiographs of 47 to 50 mature wild Leuresthes tenuis from P1 and P2 and 13 L. tenuis from P3 were taken using an analog Kramex PX-20N x-ray system (10 mA, $80 \mathrm{kVp}$, exposure times of $2 \mathrm{~s}$ ) and Kodak
Industrex type $M$ film. Radiographs were viewed against a light board to count vertebrae directly. Counts included all vertebrae between the basioccipital and urostyle (Billerbeck et al. 1997). Vertebral analysis was not conducted on the laboratoryreared fish since there was no significant difference observed in mean vertebral number among wild populations.

\section{Statistical analysis}

Statistical analyses were performed using Sigma Stat 3.11 (Systat Software) and Minitab 16.1.0. Growth capacities of laboratory-reared fish were analyzed per year and experimental period using general linear models (LMs) to test for temperature effects, population effects, and temperature $\times$ population interactions. This was followed by post hoc Tukey comparisons. The power to detect growth differences among populations was analyzed assuming a maximum difference $(\delta)$ of $0.07 \mathrm{~mm} \mathrm{~d}^{-1}$, since this represented a realistic growth rate difference that may be observed between the most widespread grunion populations based on previous findings for Atherinops affinis (maximum difference $=0.24 \mathrm{~mm}$ $\mathrm{d}^{-1}$ spanning $15^{\circ}$ latitude, Baumann \& Conover 2011). Power (P) was estimated for $\alpha=0.05$ and for both $\mathrm{n}=2$ and $\mathrm{n}=3$ replicates. Year effects on growth capacities were tested for each population using LMs with year and temperature as fixed factors. Some significant differences in mortality rates during growth trials were found among populations, but density did not have a significant impact on growth rates (LM, p > 0.05), so it was not incorporated in the analysis. Population-specific scalelength:fish-length relationships were tested for homogeneity of slopes and then for differences in intercepts using an LM with scale length as a covariate. Lengths-at-age and growth of wild fish were analyzed with LMs for each year, to test for population effects, sex effects, and population $\times$ sex interactions. Differences among years were tested with LMs within each population with sex and year as fixed factors. Since there was no correlation between vertebral number and size for 2 of the 3 populations (Spearman correlation, p > 0.05) and 2 of the correlations were positive while 1 was negative, the data were not size corrected. Vertebral numbers did not conform to normality, so KruskalWallis 1-way analyses of variance (ANOVAs) were used to test for a population effect and for sex effects within each population. 


\section{RESULTS}

\section{Thermal growth reaction norms}

In both experiments, growth capacity of Leuresthes tenuis in length and weight significantly increased with temperature across all populations (LM [length], $F[2009]_{1,10}=39.52, \mathrm{p}<0.001 ; F[2010]_{2,12}=882.78$, $\mathrm{p}<0.001$; Fig. 1). Growth rates in length (mean $\pm \mathrm{SE}$ ) for the first experimental period $(6-22 \mathrm{~mm}$ ) for 17,21 , and $25^{\circ} \mathrm{C}$ were $0.38 \pm 0.01,0.52 \pm 0.01$, and $0.67 \pm$ $0.02 \mathrm{~mm} \mathrm{~d}^{-1}$, respectively. Experiments indicated thermal limits for young $L$. tenuis, as initial rearing attempts at $27^{\circ} \mathrm{C}$ and $15^{\circ} \mathrm{C}$ failed due to high mortality $(>90 \%)$.

The power to detect a growth difference among populations was low (30-52\%) for the first experimental period in Year 1, but was sufficient (>80\%) for the second experimental period in Year 1 and for all analyses in Year 2. For Expt 1, there was some indication of increased growth capacity in length from south to north during the first experimental period. P2 and P3 grew faster than P1 at both 25 and $21^{\circ} \mathrm{C}$. P3 grew faster than P2 at $21^{\circ} \mathrm{C}$, but not at $25^{\circ} \mathrm{C}$ (Fig. 1a). However, the population effect was not significant at the 0.05 level $\left(\mathrm{LM}, F_{2,10}=3.28, \mathrm{p}=0.08\right)$. During the second half of the experiment $(22-40 \mathrm{~mm})$, growth rates among populations were similar. In Expt 2, the patterns were reversed. The more southerly P1 grew slightly but significantly faster than the more northern P2 during the first experimental period (LM, $F_{2,12}=47.81, \mathrm{p}<0.001$, Fig. $\left.1 \mathrm{~b}\right)$, with a weak but significant temperature $\times$ population effect $\left(\mathrm{LM}, F_{2,12}=5.17, \mathrm{p}=0.024\right)$. Tukey comparisons indicated that growth rates between P1 and P2 were significantly different for the $25^{\circ} \mathrm{C}$ and $21^{\circ} \mathrm{C}$ treatments, but not for the $17^{\circ} \mathrm{C}$ treatment. Again, however, growth rate differences disappeared during the second experimental period. A comparison of growth rates between years indicated that P1 fish grew significantly faster during Expt 2 compared to Expt 1 during the first experimental period (LM, $F_{1,8}=8.68, \mathrm{p}=0.019$ ), but growth rates were similar in both years for the second experimental period. There were no significant year effects for P2. There were no differences in weight growth among populations in either year.

\section{Age and growth of wild fish}

In both years, most wild Leuresthes tenuis were ages 1 and $2(96 \%$; the remaining fish were age 3). Lengths at age 1 ranged from 11 to $18 \mathrm{~cm}$, mean \pm $\mathrm{SE}=14.7 \pm 0.13 \mathrm{~cm}$. Lengths at age 2 ranged from 14 to $20 \mathrm{~cm}$ and averaged $17.2 \pm 0.12 \mathrm{~cm}$. In Year 1, average lengths at age for both 1 and $2 \mathrm{yr}$ old fish were significantly larger for P1 compared to P2 (LM, $F[\text { age } 1]_{1,41}=31.1, \mathrm{p}<0.001_{i} F[\text { age } 2]_{1,48}=22.58$, $\mathrm{p}<0.001$ ), and females were significantly larger than males $\left(\mathrm{LM}, F[\text { age } 1]_{1,41}=43.4, \mathrm{p}<0.001\right.$; $F$ [age 2$]_{1,48}=29.75, \mathrm{p}<0.001$; Table 2). There was also a significant population $\times$ sex effect for the age 1 fish $\left(\mathrm{LM}, F_{1,41}=11.7, \mathrm{p}<0.001\right)$. In Year 2, age 1 females were again significantly larger than age 1 males (LM, $\left.F_{1,70}=18.76, \mathrm{p}<0.001\right)$, but there were no size differences among populations (Table 2). In Year 2 , the P1 fish were significantly smaller than those in Year 1 at both ages 1 and 2 (LM, F[age 1 $]_{1,62}=45.07$, $\left.\mathrm{p}<0.001 ; F[\text { age } 2]_{1,21}=11.70, \mathrm{p}=0.003\right)$.

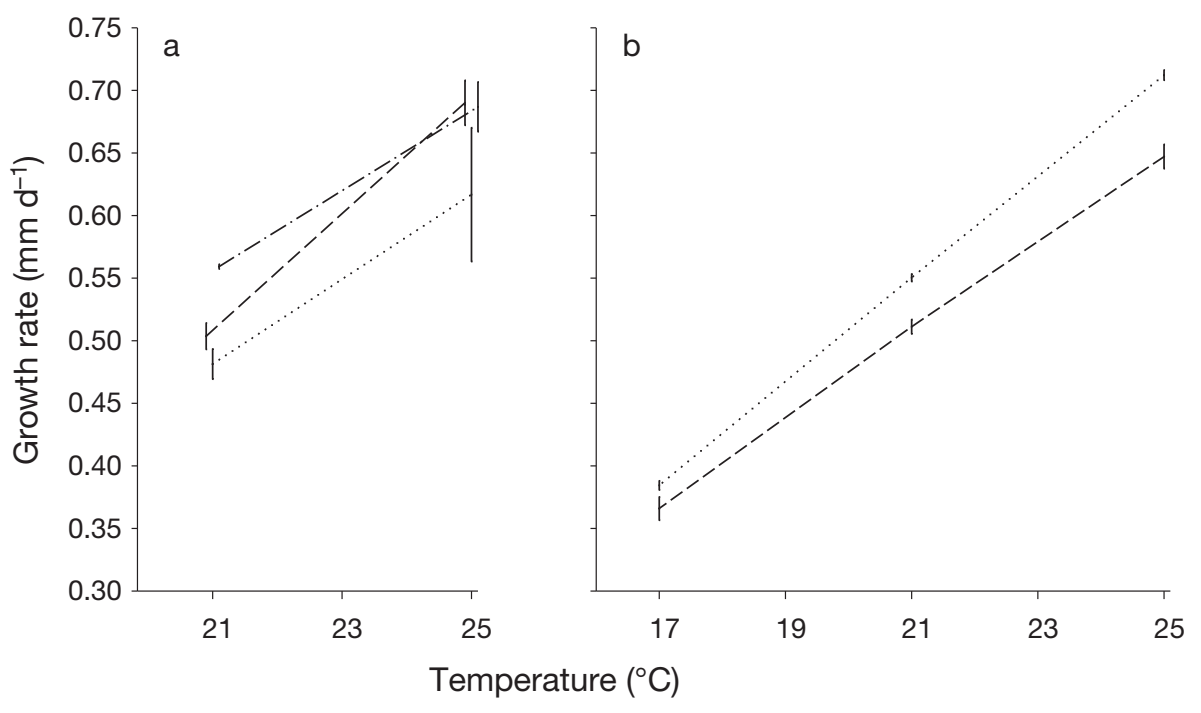

Fig. 1. Leuresthes tenuis. Thermal reaction norms of growth capacity in offspring from 3 populations along the US and Mexican Pacific coast, determined by common garden experiments in (a) 2009 and (b) 2010. Lines intersect means \pm 1 SE. For clarity, means are slightly jittered along the $x$ axis. Dotted line: P1 $\left(32^{\circ} \mathrm{N}_{i}\right.$ Ensenada, Mexico), dashed line: P2 $\left(34^{\circ} \mathrm{N}\right.$; Malibu, California, USA), dashed-dotted line: P3 $\left(37^{\circ} \mathrm{N}\right.$; Monterey, California) 
Table 2. Leuresthes tenuis. Lengths (mean $\pm \mathrm{SE}$ ) at age and average growth during Year 1 in wild grunion. Numbers inside parentheses indicate sample size. nd: no data (there was only 1 age 2 Malibu female in 2010)

\begin{tabular}{|c|c|c|c|c|c|}
\hline $\begin{array}{l}\text { Population, } \\
\text { year }\end{array}$ & Sex & $\begin{array}{l}\text { Age-1 length } \\
\text { (cm) }\end{array}$ & $\begin{array}{l}\text { Age-2 length } \\
(\mathrm{cm})\end{array}$ & $\begin{array}{l}\text { Back-calculated } \\
\text { age-1 length }(\mathrm{cm})\end{array}$ & $\begin{array}{c}\text { Growth in Year } 1 \\
\left(\mathrm{~mm} \mathrm{~d}^{-1}\right)\end{array}$ \\
\hline \multirow[t]{2}{*}{$\begin{array}{l}\mathrm{P} 1\left(32^{\circ} \mathrm{N}\right) \\
2009\end{array}$} & Male & $\begin{array}{l}14.9 \pm 0.2 \\
\quad(11)\end{array}$ & $\begin{array}{l}17.0 \pm 0.1 \\
(27)\end{array}$ & $\begin{array}{l}15.7 \pm 0.2 \\
(28)\end{array}$ & $\begin{array}{c}0.43 \pm 0.005 \\
(28)\end{array}$ \\
\hline & Female & $\begin{array}{c}18.3 \pm 0.2 \\
(5)\end{array}$ & $\begin{array}{c}18.8 \pm 0.4 \\
(8)\end{array}$ & $\begin{array}{c}17.2 \pm 0.3 \\
(8)\end{array}$ & $\begin{array}{c}0.47 \pm 0.008 \\
(8)\end{array}$ \\
\hline \multirow[t]{2}{*}{$\begin{array}{l}\mathrm{P} 1\left(32^{\circ} \mathrm{N}\right) \\
2010\end{array}$} & Male & $\begin{array}{l}14.2 \pm 0.2 \\
\quad(24)\end{array}$ & $\begin{array}{c}16.4 \pm 0.5 \\
(6)\end{array}$ & $\begin{array}{c}15.2 \pm 0.5 \\
(7)\end{array}$ & $\begin{array}{c}0.42 \pm 0.014 \\
(7)\end{array}$ \\
\hline & Female & $\begin{array}{l}15.1 \pm 0.2 \\
(26)\end{array}$ & $\begin{array}{c}17.0 \pm 0.5 \\
(4)\end{array}$ & $\begin{array}{c}15.4 \pm 0.6 \\
(4)\end{array}$ & $\begin{array}{c}0.42 \pm 0.017 \\
(4)\end{array}$ \\
\hline \multirow[t]{2}{*}{$\begin{array}{l}\text { P2 }\left(34^{\circ} \mathrm{N}\right) \\
2009\end{array}$} & Male & $\begin{array}{l}14.2 \pm 0.2 \\
(20)\end{array}$ & $\begin{array}{c}16.4 \pm 0.3 \\
(9)\end{array}$ & $\begin{array}{l}15.0 \pm 0.3 \\
\quad(13)\end{array}$ & $\begin{array}{c}0.41 \pm 0.007 \\
(13)\end{array}$ \\
\hline & Female & $\begin{array}{l}15.4 \pm 0.3 \\
\quad(10)\end{array}$ & $\begin{array}{c}17.5 \pm 0.3 \\
(9)\end{array}$ & $\begin{array}{l}15.7 \pm 0.2 \\
\quad(11)\end{array}$ & $\begin{array}{c}0.43 \pm 0.004 \\
(11)\end{array}$ \\
\hline \multirow[t]{2}{*}{$\begin{array}{l}\mathrm{P} 2\left(34^{\circ} \mathrm{N}\right) \\
2010\end{array}$} & Male & $\begin{array}{l}13.4 \pm 0.5 \\
\quad(16)\end{array}$ & $\begin{array}{c}17.0 \pm 0.2 \\
(9)\end{array}$ & $\begin{array}{l}15.2 \pm 0.2 \\
\quad(10)\end{array}$ & $\begin{array}{c}0.42 \pm 0.007 \\
(10)\end{array}$ \\
\hline & Female & $\begin{array}{c}15.4 \pm 0.6 \\
(8)\end{array}$ & nd & nd & nd \\
\hline
\end{tabular}

The intercepts of the scale-to-fish-length relationships were significantly different between populations (LM, $\left.F_{1,198}=8.49, \mathrm{p}=0.004\right)$; therefore, separate back-calculation equations were used. Both regres-

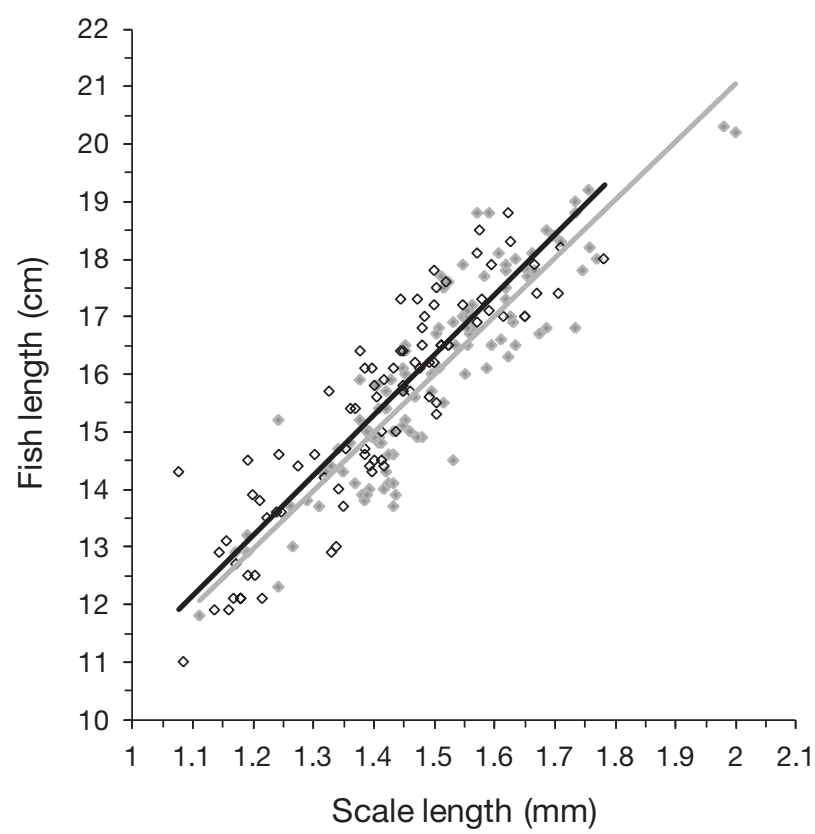

Fig. 2. Leuresthes tenuis. Scale-length:fish-length relationships for wild fish from 2 populations. and grey line: data and regression $(y=10.1 x+0.85)$ for P1 $\left(32^{\circ} \mathrm{N}\right.$; Ensenada, Mexico). $\diamond$ and black line: data and regression $(y=10.4 x+$ 0.69) for P2 (34 $\mathrm{N}_{i}$ Malibu, California, USA) sions were significantly different from 0 and fit the data very well ( $\mathrm{p}<0.001, \mathrm{R}^{2}=0.80$, Fig. 2). Growth rates based on back-calculated lengths at age 1 averaged $0.446 \pm 0.006 \mathrm{~mm} \mathrm{~d}^{-1}$ for females and $0.422 \pm$ $0.003 \mathrm{~mm} \mathrm{~d}^{-1}$ for males. Females grew significantly faster than males in both years (LM, $F[2009]_{1,56}=$ $22.1, \mathrm{p}<0.001 ; F[2010]_{1,18}=4.53, \mathrm{p}=0.047$; Table 2). The P1 fish grew faster than the P2 fish (LM, $F_{1,56}=$ $18.4, \mathrm{p}<0.001$ ) only in the first but not in the second year (Table 2).

\section{Vertebral numbers in wild fish}

Vertebral counts in the wild Leuresthes tenuis ranged from 43 to 49 , but almost all fish had either 47 or 48 vertebrae $(91 \%)$. Vertebral number did not differ significantly among populations or between males and females. Vertebral numbers (mean $\pm \mathrm{SE}$ ) for P1, P2, and P3 populations were 47.6 $\pm 0.09,47.5 \pm$ 0.13 , and $47.3 \pm 0.29$, respectively (Fig. 3).

\section{DISCUSSION}

In this study we found little evidence for genetic or phenotypic variation in growth or vertebral number among latitudinal populations of Leuresthes tenuis, indicating that $L$. tenuis does not exhibit spatial adaptations in these traits. These results contrast 


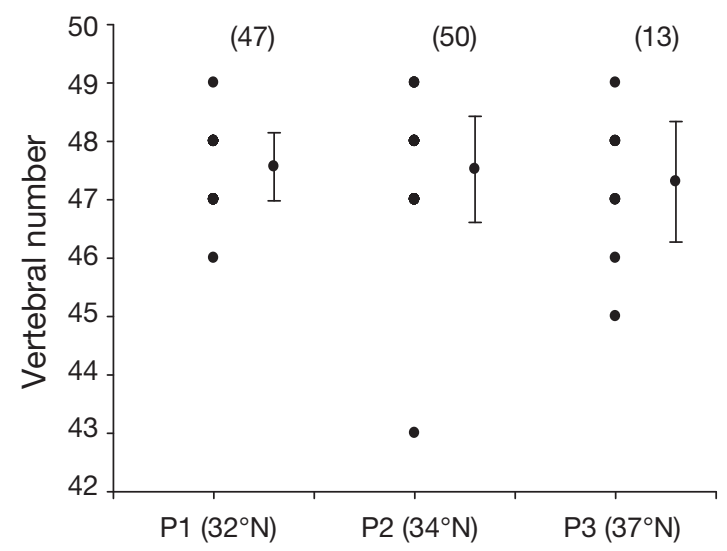

Fig. 3. Leuresthes tenuis. Vertebral numbers (mean $\pm 1 \mathrm{SD}$ ) for wild fish from 3 populations along the US and Mexican Pacific coast, represented by a single point with vertical bars. Individual points indicate the range of vertebral numbers for each population. Sample size is indicated in parentheses. P1 $\left(32^{\circ} \mathrm{N}\right)$ : Ensenada, Mexico; P2 $\left(34^{\circ} \mathrm{N}\right)$ : Malibu, California, USA; P3 $\left(37^{\circ} \mathrm{N}\right)$ : Monterey, California

with evidence for other silverside fishes, which differ from the grunion primarily in habitat (estuarine versus oceanic) (Walker 1952, Conover \& Kynard 1984). The results of our study support the notion that local adaptation may be constrained in oceanic species due to higher gene flow and weaker environmental selection pressures.

\section{Growth in Leuresthes tenuis}

Common garden experiments revealed thermal limits for larval Leuresthes tenuis, with survival and growth significantly reduced below $17^{\circ} \mathrm{C}$ or above $25^{\circ} \mathrm{C}$. Phenotypic plasticity in growth was observed, with faster growth rates occurring as temperatures increase, but there were no consistent genetic differences in growth capacity among populations (Fig. 1). In Expt 1, a weak and insignificant increase in growth rate was observed from southern to northern populations, while in Expt 2, the more southerly P1 grew slightly faster than P2. This reversed pattern was primarily due to faster growth rates by P1 during Expt 2 compared to Expt 1. The differences in growth rates among years for P1 may be the result of differences in the parental populations among years or due to high mortality rates (6-50\%) and subsequently reduced numbers of fish for length measurements in Expt 1. In both experiments, growth rates during the second experimental period $(20-40 \mathrm{~mm})$ were similar for all populations, indicating that even if slight differences in growth rates existed, they did not persist. Collectively, our results do not indicate a consistent change in genetic growth capacity with latitude and hence do not provide evidence for local growth adaptation in L. tenuis (Figs. 1 \& 4).

Consistent with Clark (1925), age and growth analysis of wild Leuresthes tenuis indicated that most
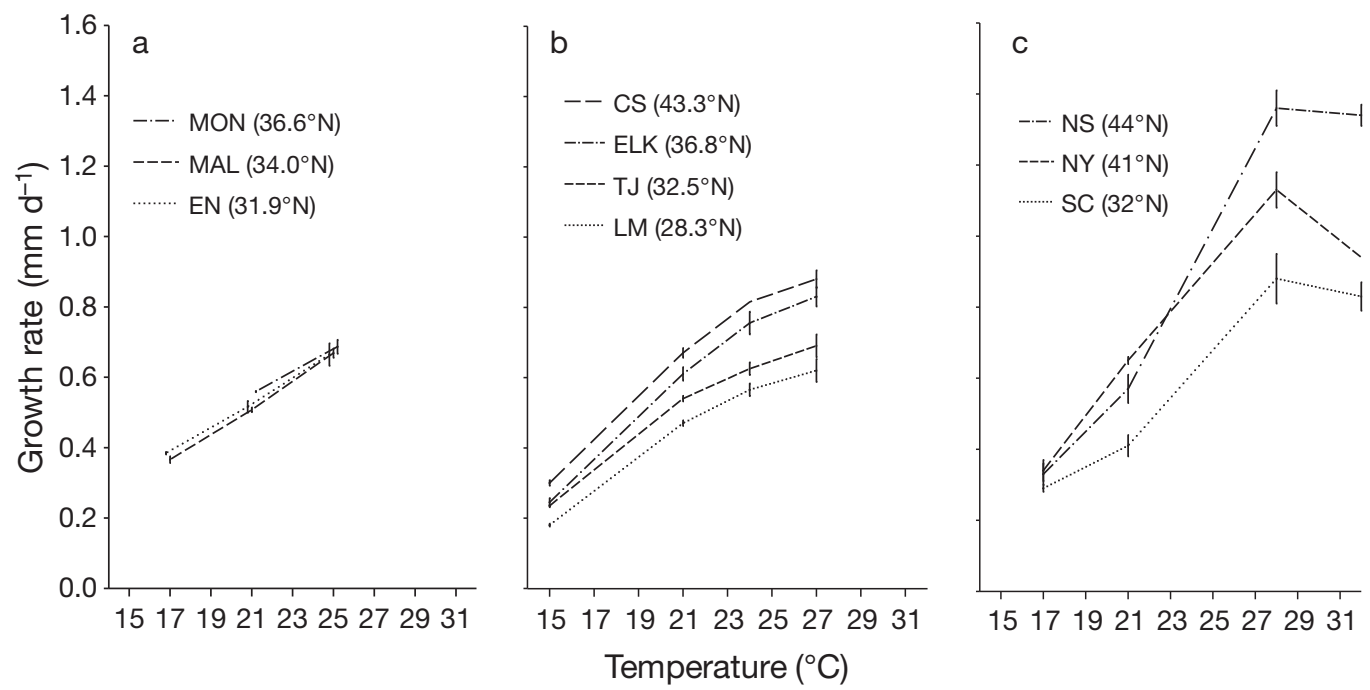

Fig. 4. Leuresthes tenuis, Atherinops affinis, and Menidia menidia. Growth capacity thermal reactions norms revealed by common garden experiments in 3 silverside species: (a) L. tenuis from this study (MON: Monterey Bay, California; MAL: Malibu, California; EN: Ensenada, Mexico); (b) A. affinis from Baumann \& Conover (2011; CS: Coos Bay, Oregon; ELK: Elkhorn Slough, California; TJ: Tijuana estuary, California; LM: Laguna Maneula, Mexico); and (c) M. menidia from Conover \& Present (1990; SC: South Carolina; NY: New York; NS: Nova Scotia). Lines intersect means \pm 1 SE. Means are slightly jittered along the $x$-axis in (a) 
spawning $L$. tenuis are ages 1 or 2 and females are larger than males. Population growth differences were inconsistent between years, similar to common garden experiments. In Year $1, L$. tenuis from P1 were significantly larger at age and had faster growth rates compared to those from P2, while in Year 2, population differences in size or growth were not observed (Table 2). The small sample size of grunion from P2 and the lack of fish available for growth calculations (those of age 2) in Year 2 may have hampered the detection of population differences. Alternatively, the variability among years may be due to large-scale changes in sea surface temperature due to El Niño events between summer 2009 through spring 2010, which could have affected the size distribution of fish at spawning. The 2010 wild P1 L. tenuis were significantly smaller than those collected in 2009, and a larger proportion were age 1. Johnson et al. (2009) found $L$. tenuis from southern California to be significantly larger than those from central California in San Francisco Bay (mean of $16.5 \mathrm{~cm}$ versus $11.9 \mathrm{~cm}$ ), suggesting that latitudinal size and growth differences may exist. Observed sizes from this study of the few adult $L$. tenuis $(\mathrm{n}=13)$ from P3 (Monterey), just south of San Francisco Bay, were $14.8 \pm 0.49 \mathrm{~cm}$ (mean $\pm \mathrm{SE}_{\text {; }} \mathrm{E}$. Brown unpublished data). If latitudinal size differences do exist, they are likely a result of phenotypic plasticity, since the slightly warmer temperatures at more southern latitudes would enable faster growth and larger sizes.

\section{Vertebral number in Leuresthes tenuis}

No differences in vertebral number were found among latitudinal populations of wild Leuresthes tenuis, thus providing no evidence for CoGV in vertebral number or Jordan's Rule (Fig. 3). Jordan's rule is commonly attributed to phenotypic plasticity in response to temperature differences among latitudes, principally during the embryonic stage (Lindsey 1975, Pavlov \& Shadrin 1998, McDowall 2008). However, genetic differences account for much of the observed vertebral variation in some fishes, suggesting that this pattern is adaptive (Billerbeck et al. 1997, Yamahira et al. 2006, Baumann et al. 2012). Vertebral variation has also been shown to be heritable in fishes (Alho et al. 2011). It has been postulated that at higher latitudes, more vertebrae may enhance swimming performance in these cooler, more viscous waters, and subsequently decrease vulnerability to predators (Swain 1988, 1992a,b), but the exact adaptive mechanism remains unresolved (McDowall 2008).
Recent work indicated that the amount of vertebral variation is strongly related to the strength of the temperature gradient (Baumann et al. 2012). Therefore, this may indicate that oceanic temperature differences across the latitudinal distribution of $L$. tenuis are too weak to evoke selection for vertebral number differences.

\section{Latitudinal variation in oceanic versus estuarine species}

The apparent lack of spatial adaptations in growth and vertebral number in Leuresthes tenuis contrasts with previous work on other silverside fishes. Growth capacity at the temperature of maximal growth increases from south to north by $4.6 \%$ per degree of latitude in the Atlantic silverside Menidia menidia and by $2.7 \%$ per degree of latitude in the Pacific topsmelt Atherinops affinis, thereby countering the environmental effect of decreasing temperatures, which would otherwise result in slower growth in northern wild populations (Conover \& Present 1990, Baumann \& Conover 2011; Fig. 4). Vertebral number also increases with latitude in estuarine silversides, at a rate of 0.42 vertebrae per degree of latitude in $M$. menidia and 0.23 vertebrae per degree of latitude in A. affinis, due to a combination of genetic and environmental factors (Billerbeck et al. 1997, Yamahira et al. 2006, Baumann et al. 2012; Fig. 5). It is possible that the small latitudinal range used in this study $\left(32-37^{\circ} \mathrm{N}\right)$ and lack of data for the northernmost site could have prevented detection of trait differences among $L$. tenuis populations. However, power analyses indicated sufficient ability to detect moderate population growth differences $(\leq 0.07 \mathrm{~mm}$ $\mathrm{d}^{-1}$ ) in laboratory-reared $L$. tenuis (with the exception of the first experimental period in 2009). Furthermore, significant population differences in estuarine silversides have been found over a latitudinal range of 4 to $5^{\circ}$ or less (Conover \& Present 1990, Billerbeck et al. 1997, Yamahira \& Conover 2002, Yamahira et al. 2006, Baumann \& Conover 2011, Baumann et al. 2012).

Although local adaptation has been found in some oceanic fishes, the absence of local adaptation in growth and vertebral number in Leuresthes tenuis supports the notion that for at least some oceanic species, adaptation may be constrained by higher gene flow levels and weaker environmental selection pressures. For L. tenuis, the potential for mixing among grunion populations is much greater than for its estuarine relatives. L. tenuis eggs are washed 


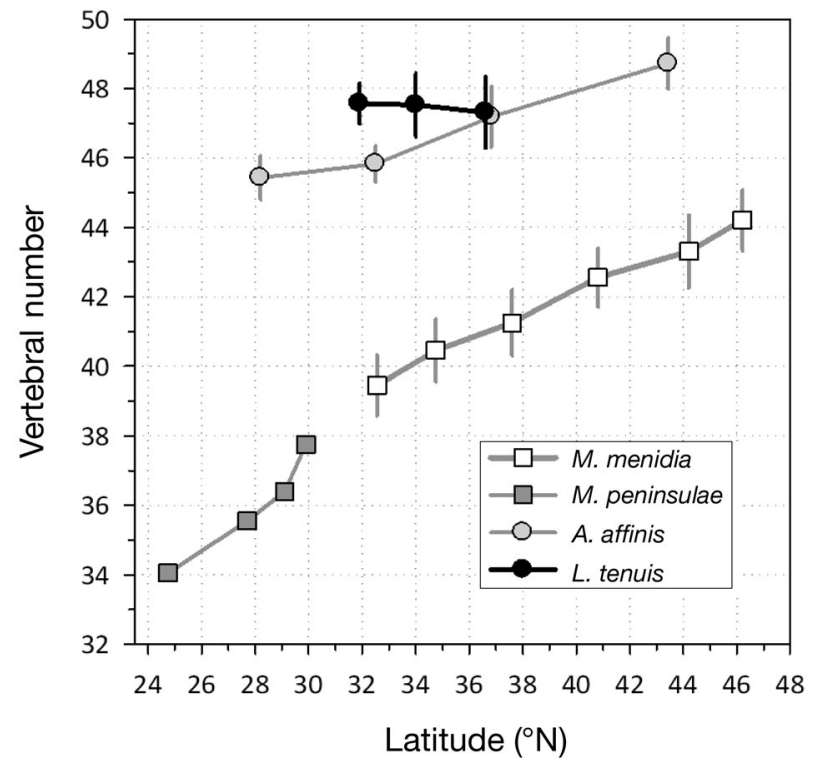

Fig. 5. Vertebral number variation (means $\pm \mathrm{SD}$ ) in the wild across latitudinal gradients in atherinopsid species: Leuresthes tenuis from this study, Atherinops affinis from Baumann et al. (2012), Menidia menidia from Billerbeck et al. (1997), and M. peninsulae from Yamahira et al. (2006)

from open-ocean beach spawning sites into nearshore waters, at which point hatching is triggered (Walker 1952, Griem \& Martin 2000) and larvae may be carried great distances by ocean currents. There is also evidence that adult $L$. tenuis move along the coast, as indicated by their recent colonization and northward expansion, likely during atypical warm pulses, into San Francisco Bay and Tomales Bay (Roberts et al. 2007). In contrast, estuarine silversides lay their eggs attached to submerged vegetation in the intertidal zone of semi-enclosed bays and estuaries and their larvae remain very close to shore (Conover \& Kynard 1984, Griffin \& Valiela 2001). Additionally, many estuarine and anadromous species are also known to exhibit natal homing, although in Menidia menidia, natal homing was found to be less frequent than in other intertidal-dependent species (Clarke et al. 2010).

The lack of genetic structure found in Leuresthes tenuis in this study supports previous findings from population genetic studies on L tenuis. The majority of results in an allozyme study by Gaida et al. (2003) pointed to a panmictic population structure with little divergence across southern California. A recent microsatellite and mitochondrial study also found little evidence of genetic differentiation between $L$. tenuis from central California (San Francisco Bay) and southern California (Johnson et al. 2009). How- ever, it was suggested that the disjunct northern populations, including Monterey Bay (P3) and San Francisco Bay could be recent colonizations that have not yet had time to diverge (Johnson et al. 2009). L. tenuis were only thought to have colonized San Francisco Bay a decade ago (Johnson et al. 2009), but $L$. tenuis in Monterey Bay were reported by Phillips (1943), and spawning has been observed nearly annually since the mid-1990s (Roberts et al. 2007); for at least the Monterey Bay population, there has likely been sufficient time to allow for adaptations in life history and morphological traits to be expressed. Overall, these studies together with our results suggest a high level of mixing among $L$. tenuis populations.

However, high gene flow, although shown to be an evolutionary-constraining force (Felsenstein 1976, Slatkin 1987), may not be able to completely limit local adaptations in all cases. This is evidenced by the fact that local adaptation is seen in some oceanic species, such as Atlantic cod (Purchase \& Brown 2001, Salvanes et al. 2004) and turbot (Imsland et al. 2000). In some of the oceanic species for which adaptation has been observed, it is possible that dispersal is more limited than in other oceanic fishes (Fairbairn 1981, Grant et al. 1984, Diakov 1998, Foss et al. 1998, Shulman 1998). Alternatively, high selection pressures imposed on these species may be enabling adaptation to persist in the face of high population mixing (Schneider et al. 1999, Saint-Laurent et al. 2003).

For Leuresthes tenuis, environmental selection pressures are likely to be weak, hence contributing to the lack of local adaptations found in this species. The Pacific coast of North America, where L. tenuis is found, is a relatively weak latitudinal thermal gradient with only small latitudinal and seasonal sea surface temperature variations (Baumann \& Conover 2011). Additionally, environmental variation is even less likely in the oceanic environment of the grunion compared to estuarine environments, since the latter is influenced by terrestrial conditions and may undergo rapid heating and cooling. For example, mean winter versus summer temperatures vary from 13 to $22.5^{\circ} \mathrm{C}$ in Tijuana estuary (San Diego, California) and from 10.5 to $19^{\circ} \mathrm{C}$ in Elkhorn Slough (Monterey), with maximum temperatures of $30^{\circ} \mathrm{C}$ in Tijuana and $24^{\circ} \mathrm{C}$ in Elkhorn Slough (National Estuarine Research Reserve System Centralized Data Management Office http://cdmo.baruch.sc.edu/, stations OS and SM for 2008 and 2009). In comparison, mean winter versus summer temperatures vary from 14 to $22^{\circ}$ (maximum: $24^{\circ} \mathrm{C}$ ) off the coast of San Diego, 
and 10 to $15^{\circ} \mathrm{C}$ (maximum: $16.5^{\circ} \mathrm{C}$ ) off Monterey (National Weather Service www.ndbc.noaa.gov/, buoys 46232 and 46236 for 2008 and 2009). It has also been suggested that $L$. tenuis larvae seek out warm microhabitats, such as bays, particularly in northern areas where coastal water temperatures are cool (Roberts et al. 2007, Johnson et al. 2009). This hypothesis is supported by experiments in this study, which indicated a very narrow thermal tolerance for L. tenuis larvae, especially compared to its estuarine relatives (Fig. 4). Thus, latitudinal temperature differences and environmental selection pressures experienced by $L$. tenuis are likely small.

The balance between gene flow and natural selection may be used to explain the lack of local adaptation found in Leuresthes tenuis and the varying degrees of adaptation within the silverside family (Felsenstein 1976, Lenormand 2002, Conover et al. 2006). In a previous study, the Pacific Atherinops affinis was found to have half the amount of among-population genetic variation seen in the Atlantic Menidia menidia, reflecting the much weaker environmental gradient on the Pacific versus Atlantic coast (Baumann \& Conover 2011, Baumann et al. 2012). This study provided novel insight by examining adaptation in a silverside with a divergent life history. In $L$. tenuis adaptation was not evident, likely due to the fact that higher gene flow levels were able to override the relatively weak environmental selection pressures that $L$. tenuis experience.

The results of our study suggest that while spatial adaptation patterns are commonplace in estuarine or anadromous fishes, their prevalence may not extend to more oceanic fishes. Some oceanic fishes may display local adaptations, particularly those under high selection or those in which dispersal is restricted, but for oceanic fishes in which there is ample mixing and that are found along weak environmental gradients, we may expect genetic adaptations to be limited.

\section{Implications for climate change}

Knowledge of the genetic and environmental variation found within species across their natural climate gradients may provide clues to potential evolutionary responses to global climate change (Merilä et al. 2001, Garant et al. 2004). It has been postulated that ectotherms will adapt to global climate change through a CnGV mechanism that will involve a poleward shift in genotypes, either through distribution shifts or natural selection, to counter the plastic effects of the changing environment (Baumann \&
Conover 2011). However, for species like Leuresthes tenuis that do not show local adaptations, the entire population will need to adapt as a single unit. This could make adaptation more challenging, since the population will not be able to respond differentially across its range. Additionally, oceanic species with narrow thermal ranges, like $L$. tenuis, may be at a further disadvantage compared to species adapted to more variable environments (i.e. estuarine species; Tewksbury et al. 2008). For L tenuis, further complications arise because eggs are deposited in sandy beach habitats (Walker 1952). At the southern end of its range, egg survival may be threatened by increasing beach temperatures (David 1939, Hubbs, 1965), while expansion of $L$. tenuis northward will be dependent on whether it is able to find suitable beach spawning habitat.

Acknowledgements. We thank many people for assisting with field sampling: K. Martin and the Grunion Greeters, J. A. Rosales-Casián, G. Bernadi, C. Moravek, and T. Duffy. Additionally, we are greatly appreciative of B. Chamberlain and S. Abrams for their help ensuring the success of our experiments at Flax Pond Laboratory. This study was funded by a grant from the US National Science Foundation (OCE0425830) to D.O.C.

\section{LITERATURE CITED}

Alho JS, Leinonen T, Merilä J (2011) Inheritance of vertebral number in the three-spined stickleback (Gasterosteus aculeatus). PLoS ONE 6:e19579

Baumann H, Conover DO (2011) Adaptation to climate change: contrasting patterns of thermal-reaction-norm evolution in Pacific versus Atlantic silversides. Proc R Soc Lond B Biol Sci 278:2265-2273

Baumann H, Rosales-Casián JA, Conover DO (2012) Contrasting latitudinal variation in vertebral number and sex determination in Pacific versus Atlantic silverside fishes. Copeia 2012:341-350

Bernardi G, Findley L, Rocha-Olivares A (2003) Vicariance and dispersal across Baja California in disjunct marine fish populations. Evolution 57:1599-1609

> Billerbeck JN, Orti G, Conover DO (1997) Latitudinal variation in vertebral number has a genetic basis in the Atlantic silverside, Menidia menidia. Can J Fish Aquat Sci 54:1796-1801

Clark FN (1925) The life history of Leuresthes tenuis, an atherine fish with tide controlled spawning habitats. Calif Fish Game 10:1-51

Clarke LM, Munch SB, Thorrold SR, Conover DO (2010) High connectivity among locally adapted populations of a marine fish (Menidia menidia). Ecology 91:3526-3537

> Conover DO, Kynard BE (1984) Field and laboratory observations of spawning periodicity and behavior of a northern population of the Atlantic silverside, Menidia menidia (Pisces, Atherinidae). Environ Biol Fishes 11:161-171

Conover DO, Present TMC (1990) Countergradient variation in growth rate: compensation for length of the grow- 
ing-season among Atlantic silversides from different latitudes. Oecologia 83:316-324

- Conover DO, Schultz ET (1995) Phenotypic similarity and the evolutionary significance of countergradient variation. Trends Ecol Evol 10:248-252

Conover DO, Clarke LM, Munch SB, Wagner GN (2006) Spatial and temporal scales of adaptive divergence in marine fishes and the implications for conservation. J Fish Biol 69:21-47

> Conover DO, Duffy TA, Hice LA (2009) The covariance between genetic and environmental influences across ecological gradients: reassessing the evolutionary significance of countergradient and cogradient variation. Ann NY Acad Sci 1168:100-129

> David LR (1939) Embryonic and early larval stages of the grunion, Leuresthes tenuis, and the sculpin, Scorpaena guttata. Copeia 1939:75-81

- Deutsch CA, Tewksbury JJ, Huey RB, Sheldon KS, Ghalambor CK, Haak DC, Martin PR (2008) Impacts of climate warming on terrestrial ectotherms across latitude. Proc Natl Acad Sci USA 105:6668-6672

> Diakov YP (1998) Population structure of the Pacific black halibut Reinhardtius matsuurae Jordan et Snyder. J Sea Res 40:109-116

Eschmeyer WN, Herald ES, Hammann H (1983) A field guide to Pacific coast fishes of North America. Houghton Mifflin Company, Boston, MA

Fairbairn DJ (1981) Which witch is which? A study of the stock structure of witch flounder (Glyptocephalus cynoglossus) in the Newfoundland region. Can J Fish Aquat Sci 38:782-794

Felsenstein J (1976) The theoretical population genetics of variable selection and migration. Annu Rev Genet 10: 253-280

Foss A, Imsland AK, Nevdal G (1998) Population genetic studies of the Atlantic halibut in the North Atlantic Ocean. J Fish Biol 53:901-905

> Gaida IH, Buth DG, Matthews SD, Snow AL, Luo SB, Kutsuna S (2003) Allozymic variation and population structure of the California grunion, Leuresthes tenuis (Atheriniformes: Atherinopsidae). Copeia 2003:594-600

Garant D, Kruuk LEB, McCleery RH, Sheldon BC (2004) Evolution in a changing environment: a case study with great tit fledging mass. Am Nat 164:E115-E129

Garcia-Ramos G, Kirkpatrick M (1997) Genetic models of adaptation and gene flow in peripheral populations. Evolution 51:21-28

> Grant WS, Teel DJ, Kobayashi T, Cyreis S (1984) Biochemical population genetics of Pacific halibut (Hippoglossus stenolepis) and comparison with Atlantic halibut (H. hippoglossus). Can J Fish Aquat Sci 41:1083-1088

Griem JN, Martin KLM (2000) Wave action: the environmental trigger for hatching in the California grunion Leuresthes tenuis (Teleostei: Atherinopsidae). Mar Biol 137:177-181

> Griffin MPA, Valiela I (2001) $\mathrm{d}^{15} \mathrm{~N}$ isotope studies of life history and trophic position of Fundulus heteroclitus and Menidia menidia. Mar Ecol Prog Ser 214:299-305

Hubbs C (1965) Developmental temperature tolerance and rates of four southern California fishes, Fundulus parvipinnis, Atherinops affinis, Leuresthes tenuis, and Hypsoblennius sp. Calif Fish Game 51:113-122

Imsland AK, Foss A, Nevdal G, Cross T, Bonga SW, Ham EA, Stefansson SO (2000) Countergradient variation in growth and food conversion efficiency of juvenile turbot.
J Fish Biol 57:1213-1226

> Johnson PB, Martin KL, Vandergon TL, Honeycutt RL, Burton RS, Fry A (2009) Microsatellite and mitochondrial genetic comparisons between northern and southern populations of California grunion (Leuresthes tenuis). Copeia 2009:465-474

Jonassen TM, Imsland AK, Fitzgerald R, Bonga SW and others (2000) Geographic variation in growth and food conversion efficiency of juvenile Atlantic halibut related to latitude. J Fish Biol 56:279-294

Jordan D (1891) Relations of temperature to vertebrae among fishes. Proc US Natl Mus 14:107-120

Kokita T (2003) Potential latitudinal variation in egg size and number of a geographically widespread reef fish, revealed by common-environment experiments. Mar Biol 143:593-601

- Lenormand T (2002) Gene flow and the limits to natural selection. Trends Ecol Evol 17:183-189

Levins R (1968) Evolution in changing environments. Princeton University Press, Princeton, NJ

Levins R (1969) Thermal acclimation and heat resistance in Drosophila species. Am Nat 103:483-499

> Lindsey CC (1975) Pleomerism, the widespread tendency among related fish species for vertebral number to be correlated to maximum body length. J Fish Res Board Can 32:2453-2469

> McDowall RM (2008) Jordan's and other ecogeographical rules, and the vertebral number in fishes. J Biogeogr 35: 501-508

> Merilä J, Kruuk LEB, Sheldon BC (2001) Cryptic evolution in a wild bird population. Nature 412:76-79

Moffatt NM, Thomson DA (1978) Tidal influence on the evolution of egg size in the grunions (Leuresthes, Atherinidae). Environ Biol Fishes 3:267-273

Pavlov DA, Shadrin AM (1998) Development of variation in the number of myomeres and vertebrae in the white sea herring, Clupea pallasi marisalbi, under the influence of temperature. J Ichthyol 38:251-261

Phillips JB (1943) Grunion in Monterey Bay. Calif Fish Game 29:82

> Purchase CF, Brown JA (2001) Stock-specific changes in growth rates, food conversion efficiencies, and energy allocation in response to temperature changes in juvenile Atlantic cod. J Fish Biol 58:36-52

Roberts D, Lea RN, Martin KLM (2007) First record of the occurrence of the California grunion, Leuresthes tenuis, in Tomales Bay, California; a northern extension of the species. Calif Fish Game 93:107-110

Saint-Laurent R, Legault M, Bernatchez L (2003) Divergent selection maintains adaptive differentiation despite high gene flow between sympatric rainbow smelt ecotypes (Osmerus mordax Mitchill). Mol Ecol 12:315-330

Salvanes AGV, Skjaeraasen JE, Nilsen T (2004) Sub-populations of coastal cod with different behaviour and life history strategies. Mar Ecol Prog Ser 267:241-251

Schneider CJ, Smith TB, Larison B, Moritz C (1999) A test of alternative models of diversification in tropical rainforests: ecological gradients vs. rainforest refugia. Proc Natl Acad Sci USA 96:13869-13873

> Shulman MJ (1998) What can population genetics tell us about dispersal and biogeographic history of coral-reef fishes? Aust J Ecol 23:216-225

Slatkin M (1987) Gene flow and the geographic structure of natural populations. Science 236:787-792

Swain DP (1988) Evidence of selection for vertebral number 
of fry in peamouth, Mylocheilus caurinus. Can J Fish Aquat Sci 45:1279-1290

Swain DP (1992a) The functional basis of natural selection for vertebral traits of larvae in the stickleback Gasterosteus aculeatus. Evolution 46:987-997

Swain DP (1992b) Selective predation for vertebral phenotype in Gasterosteus aculeatus: reversal in the direction of selection at different larval sizes. Evolution 46:998-1013

Tewksbury JJ, Huey RB, Deutsch CA (2008) Putting the heat on tropical animals. Science 320:1296-1297

Walker BW (1949) Periodicity of spawning by the grunion,

Editorial responsibility: Hans-Heinrich Janssen,

Oldendorf/Luhe, Germany
Leuresthes tenuis, an antherine fish. $\mathrm{PhD}$ dissertation, University of California, Los Angeles, CA

Walker BW (1952) A guide to the grunion. Calif Fish Game 38:409-420

Yamahira K, Conover DO (2002) Intra- vs. interspecific latitudinal variation in growth: adaptation to temperature or seasonality? Ecology 83:1252-1262

Yamahira K, Lankford TE, Conover DO (2006) Intra- and interspecific latitudinal variation in vertebral number of Menidia spp. (Teleostei: Atherinopsidae). Copeia 2006: 431-436

Submitted: November 25, 2011; Accepted: May 7, 2012

Proofs received from author(s): July 27, 2012 